\title{
Correction Factors for Important Prey Categories in the Diet of Domestic Cats
}

\author{
Olof LIBERG
}

\begin{abstract}
Liberg O., 1982: Correction factors for important prey categories in the diet of domestic cats. Acta theriol., 27, 9. 115-122 [With 3 Tables] Feeding experiments were carried out to estimate ratio between ingested amounts of prey, and undigested part of that same prey in faeces (=correction factors) of the domestic cat in Southern Sweden. It was found that only hair and feathers in faeces could be used to estimate such ratios. Variations in the ratios found were wide for large prey like adult rabbits. To determine amount of prey eaten per cat and day, defecation rate was also determined. An equation for calculating daily intake of different prey animals was proposed. The correction factors were tested in the proposed equation on a sample of faeces from feral cats, that live almost entirely on natural prey. The computed value of daily intake of natural prey differed less than $15 \%$ from the expected value, based on the theoretical daily energy requirement of the cats. It was therefore concluded that the test result supported the validity of the correction factors found in this study.

[Departament of Animal Ecology, University of Lund, Ecology, Building, Helgonavägen 5, S-223 62 Lund, Sweden.]
\end{abstract}

\section{INTRODUCTION}

Undigested remains of prey in scats are frequently used to determine food habits of carnivores. A few authors have computed correction factors to determine the proportion of different prey in the diet for some carnivores, such as fox (Lockie, 1959; Goszczyński, 1974) and wolf (Floyd et al., 1978). Lockie and Goszczyński assumed that all important parts of the fox' diet did leave undigestable parts in the faeces that could be identified. Hence, in determining composition of the diet they summed up the weights of all prey remnants in a sample of scats, corrected back to prey intake, and set the sum as one hundred of the animals food intake. This is not possible for domestic cats, where natural prey often makes up less than half of the total food intake; the rest is food given by humans, that mostly leave no identifiable remains. One way to overcome this difficulty is to determine the amount of prey remains, per defecation. ${ }^{1}$ If defecation rate or number of scats shed per day,

1 The term "defecation" here means both the process of shedding faeces, and the total amount of faeces shed at one time. 
is constant, irrespective of food intake, it should be possible to caulculate the percentages of daily food intake for each prey type, e.g.: if a grams of remains in faeces of one type of prey corresponds to $b$ grams of that prey type eaten, and defecation rate per day is $d$, then the total amount of that prey eaten per day and cat is given by the equation (1):

$$
x=y(b / a) d
$$

where $x$ is the amount of that prey type eaten per day, and $y$ is the amount of undigested parts of that prey type found per defecation The factor $b / a$ corresponds to the correction factor mentioned above. These correction factors are, of course different for different prey types.

The domestic cat is an important predator in various ecosystems (Ryszkowski et al., 1973; George, 1974) and it is urgent to obtain a method for calculating the relative importance of common prey items. The present study was conducted to develop such a method, including the determination of correction factors for common prey of the domestic cat in Sweden, and of defecation rate of cats.

\section{METHODS}

Cats were kept separate in cages, $1.2 \times 2.0 \times 0.6 \mathrm{~m}$, and were fed with carcasses of the examined prey. Before each test the cats were fed with fish or pet food for four days. The cats were weighed before and after the tests. In most tests only one type of prey was given, but in a few cases a mixed diet was presented to the cats. The food was weighed before given to the cats, and remnants left in the cages were taken out and weighed. Large prey, such as fowls and adult rabbits were left in the cage for two days before taken out. The cages were cleaned of faeces twice a day. When collecting faeces, it was determined whether it emanated from one or more defecations. This was usually simple, since all scats from each defecation usually were deposited in one pile, and the cat did rarely defecate more than once between each control. In the field, definition of one defecation never is any problem. Observations were made of the cats' way of consuming different prey animals.

Scats were dried in an oven kept at $60^{\circ} \mathrm{C}$ for three days, and were then weighed. They were then washed in a sieve with $1.4 \mathrm{~mm}$ wire mesh. Experiments showed that about $20 \%$ of the hair went through this wide mesh (checked with a $0.5 \mathrm{~mm}$ mesh kept under the ordinary sieve), but as cat faeces usually contain a large proportion (often $>90 \%$ ) of amorf material, they are very difficult to clean in a finer mesh. The washing was continued till the water pressed through the hair - or faetherball was clean. Hair, feathers, teeth and bones then were examined macroscopically. In a few cases, where a mixed diet had been given, microscopical analysis of the hair was done according to Brunner \& Coman (1974). The undigested material was then again oven-dried and weighed. 


\section{RESULTS AND DISCUSSION}

\subsection{Correction Factors}

Nine different cats, four females and five males were used in the tests. They all maintained their original weight during the tests. The tests were performed between 20 Sep and 16 Oct, 1977, and between 22 Sep and $23 \mathrm{Dec}$, 1978. Eleven different prey types were given in different amounts to different cats. The three most common prey types of cats in Southern Sweden were given in more than two tests, to make estimation of variance possible. These categories were small rodents (excluding water voles), juvenile rabbits $(300-500 \mathrm{~g}$ body weigth) and adult rabbits ( $1000-1700 \mathrm{~g}$ body weight). It was found that the amount of bone in faeces varied greatly, probably because the digestibility of bones varies between different cats, and also for the same individual, maybe depending on amount and composition of the food. Also cats consume a different proportion of the bones for large prey like rabbits. Usually less then $10 \%$ of the undigested material of small prey like voles, mice and passerines was made up of bones and teeth. It was therefore decided to use only the weights of hair and feathers for determination of correction factors. Claws, bills and similar structures were treated as bones.

As was expected from the surface: volume ratio of different prey categories, a larger proportion of small prey than of larger prey remained undigested in the faeces (Table 1). This was also observed by Lockie (1959) and Goszczyński (1974). The correction factors found in this study were larger than those calculated by both Lockie and Goszczyński for all prey categories. The reason might be that I lost some hair in the hard washing procedure, and that bones were not included in the calculations or that they worked with another predator (fox) which perhaps digests it's prey differently. The discrepancy was largest for the largest prey, such as adult rabbits, but here it is also quite likely that cats leave a larger proportion of the undigestable parts of the prey uneaten, than foxes do. Cats in different tests ate both different amounts and different parts of the rabbits, which might account for the higher variance for this prey category. However, most cats ate the rabbits in the same general pattern, starting with the neck and head, to continue with the chest, including lungs and heart, and finishing with the hindquarters and legs. Of an adult rabbit, nose, upperjaws, ears, back-skin with tail, part of the spine and lower parts of the legs were usually left uneaten.

When remains of more than one type of prey occurs in a scat, they should be separated. Hairs of lagomorphs and rodents are easily sepa- 


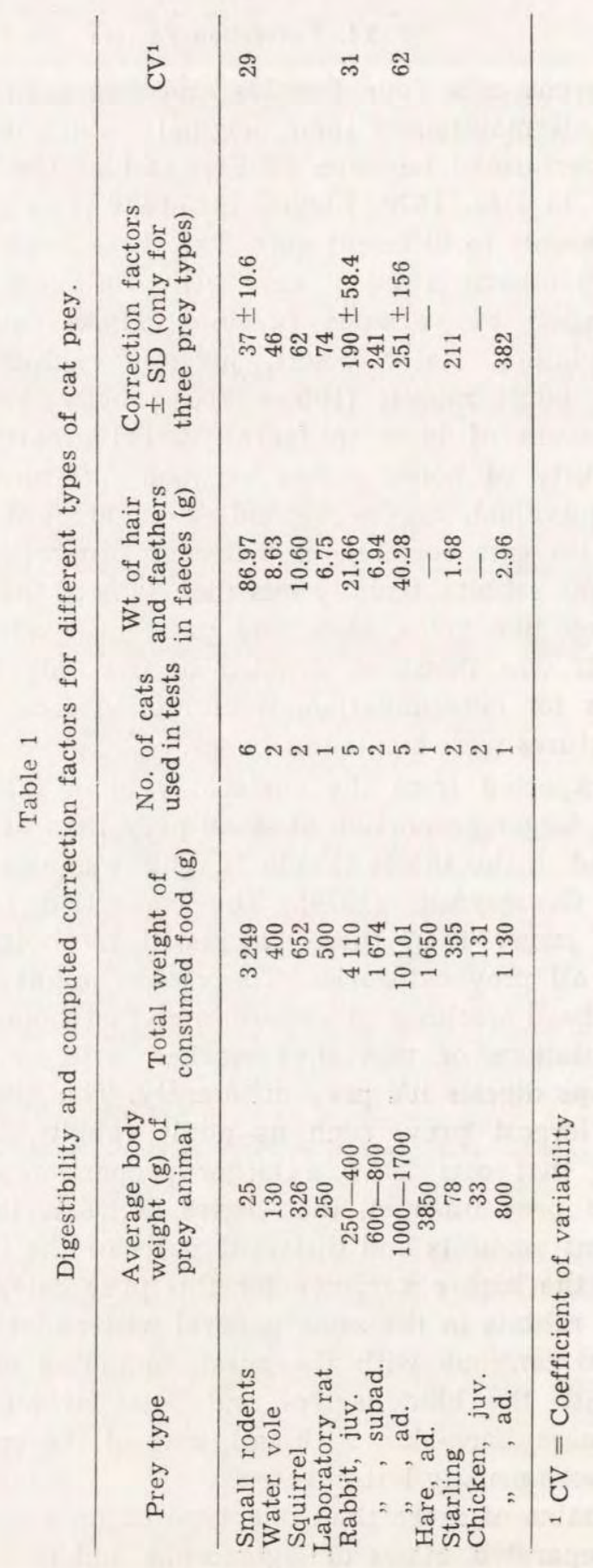


rated macroscopically, but if more than one species of rodent occurs in the scat, they can be separated either by the frequency of occurrence of teeth (according to Lockie 1959), or by some standard routine in the selection of hair for microscopical analysis. In this study, a sample of five tufts of coat hairs were picked up from all parts of a complete cleaned defecation. If hairs of only one species occurred in the cross-section of one tuft, it was given a score of $1 / 5$, if two species occurred each one got a score of $1 / 10$, and if three species occurred in the same cross-section they got $1 / 15$, each, and so on. When all five tufts have been analysed, the sum of all scores will be 1 , and each species has got a score sum that is a fraction of 1 . This fraction is then multiplied with the total weight of rodent hairs in the defecation, to give the weight of hairs for each species in the defecation. If there is little hair in a defecation, then less than five tufts might be enough to determine the proportion of rodent species in the defecation.

In the tests where adult hares and juvenile chickens were given, no remains were found in faeces. Concerning the chickens, the reason probably was that the immature down feathers and the soft bones were completely digested. This means that faeces analysis is an inappropriate method to examine cat predation on juvenile birds. It seems that the same could be the case for foxes, as in a field study of the Wildlife Research Group of Lund University, no remains of immature pheasants were found in a large sample of summer scats of fox, although remains of many adult pheasants were found in the same sample (von Schantz, 1980 and pers. comm.).

For adult hares, the reason obviously was a result of the feeding technique; the cat opened the hare and ate from inside without digesting any hair or bones.

\subsection{Determination of Defecation Rate}

Defecation rate (number of defecations per cat and day) varied less between the nine different cats, than did number of scats shed per day (Table 2). Although the amount of natural prey consumed by the cats, and thus also amount of hair to get rid off each day, varied tenfold, the defecation rate did not vary more than twofold. The average defecation rate was 1.02 , with a coefficient of variability of 23 . Howard (1957) found that one cat kept in captivity for 15 days, had a defecation rate of 1.07, and Fitzgerald \& Karl (1979) used the approximate defecation rate of one, in their calculations of cat predation on natural prey in New Zealand, 
On basis of this, I considered it safe to assume that defecation rate is a constant factor, and that the approximate value of 1.0 can be used in equation (1).

\subsection{Test of Correction Factors}

The validity of the correction factors for different prey categories, found in this study, could be tested on a sample of scats from male cats collected in the Revinge area in Southern Sweden in 1974-76. These cats are not fed by humans, but maintain themselves almost completely on natural prey (Liberg, 1980). If we assume that these cats are neither fattening nor starving, then their prey intake should

Table 2

Defecation rate and number of scats shed per day in relation to amount of prey eaten per day, and amount of hair shed per day. All the cats got a total of $300-400$ gram food per day. ${ }^{1}$

\begin{tabular}{|c|c|c|c|c|c|}
\hline $\begin{array}{l}\text { Tested } \\
\text { cats }\end{array}$ & $\begin{array}{l}\text { Number of } \\
\text { test days }\end{array}$ & $\begin{array}{l}\text { Weight of prey } \\
\text { eaten per day } \\
\text { (g) }\end{array}$ & $\begin{array}{l}\text { Amount of hair } \\
\text { or feathers } \\
\text { shed per day } \\
\text { (g) }\end{array}$ & $\begin{array}{l}\text { Defecation } \\
\text { rate per day }\end{array}$ & $\begin{array}{l}\text { Number of } \\
\text { scats } \\
\text { per day }\end{array}$ \\
\hline$\sigma^{x} 1$ & 13 & 376 & 3.06 & 1.08 & 6.8 \\
\hline ○ 2 & 23 & 215 & 1.77 & 1.35 & 9.2 \\
\hline$\sigma^{\pi} 3$ & 23 & 205 & 1.71 & 1.17 & 6.4 \\
\hline ㅇ 4 & 16 & 72 & 1.31 & 0.94 & 3.5 \\
\hline$\sigma^{7} 5$ & 46 & 140 & 0.99 & 0.87 & 4.0 \\
\hline ㅇ 6 & 21 & 104 & 0.73 & 0.66 & 2.3 \\
\hline$\sigma^{\pi} 7$ & 22 & 107 & 0.72 & 0.77 & 3.9 \\
\hline ○ 8 & 8 & 67 & 0.21 & 1.23 & $?$ \\
\hline $0^{x} 9$ & 13 & 33 & 0.11 & 1.15 & $?$ \\
\hline $\begin{array}{l}\mathrm{X} \pm \mathrm{SD} \\
\mathrm{CV}\end{array}$ & & $147 \pm \frac{105}{71}$ & $1.18 \pm 0.92$ & $1.02 \pm \frac{0.23}{23}$ & $5.16 \pm 2.40$ \\
\hline
\end{tabular}

${ }_{1}$ Including prey and non-prey food.

approximately equal their theoretical food or energy requirement. The average prey intake of these cats was calculated on basis of hair and feather remains in the mentioned scat sample (Table 3), with the aid of equation (1), where defecation rate was set at 1.0 (this actually means that prey amount per defecation is the same as prey amount per cat and day, as one cat defecates once per day). The result of the calculations was, that these cats on average in the years of $1974-76$ ate $\mathbf{2 8 2}$ grams of prey per cat and day (Table 3 ).

The theoretical food requirement was taken from the literature. Scott (1968) estimated that "adult cats" (she used two males and two females in the feeding tests) required 62 grams of meat per day and $\mathrm{kg}$ body-weight. The average weight of 16 feral cats in the Revinge area was $4.3 \mathrm{~kg}$ (Liberg unpubl.). That means that they would need 
267 grams of pure meat per day. Another, and maybe more correct way of determining the amount of food these cats would need per day, would be to combine the calculated energy requirement of cats with the energy content of their natural prey. Both Graves (1965) and Scott (1968) report that the energy requirement of adult male cats is $80 \mathrm{Kcal}$ per day and $\mathrm{kg}$ body-weight. Hansson et al. (1970) estimated the energy content of Microtus agrestis L. (an important prey species for cats in this area) to be $1.46 \mathrm{Kcal}$ per gram fresh weight. Based on these figures, the intake of a $4.3 \mathrm{~kg}$ cat would be 236 gram (assuming that other prey species have about the same energy content as Microtus).

Table 3

Amount of hair of feathers per defection in a sample of 126 defecations from feral cats in the Revinge area in 1974-76, and amount of prey per cat and day, calculated on basis of these prey remains with the application of correction factors determined in this study. Symbols are the same as in equation (1). Defection rate $d=1.0$. Correction factors $(b / a)$ are given within brackets for each prey type. Total amount of prey: $282 \mathrm{~g}$.

\begin{tabular}{lccccc}
\hline & $\begin{array}{c}\text { Small } \\
\text { rodents } \\
(b / a=37)\end{array}$ & $\begin{array}{c}\text { Water-vole } \\
(b / a=46)\end{array}$ & $\begin{array}{c}\text { Rabbits } \\
(b / a=206-251)\end{array}$ & $\begin{array}{c}\text { Small } \\
(b / a=211)\end{array}$ & $\begin{array}{c}\text { Birds } \\
(b / a=382)\end{array}$ \\
\hline $\begin{array}{l}\text { Amount of hair } \\
\text { (feathers) per } \\
\text { defecation }(y)\end{array}$ & 1.95 & 0.10 & 0.84 & 0.004 & 0.008 \\
$\begin{array}{l}\text { Amount of prey } \\
\text { per cat and day } \\
\begin{array}{l}x=y(b / a) \quad 1.0]\end{array}\end{array}$ & 72.2 & 4.6 & 201.6 & 0.8 & 2.9 \\
\hline
\end{tabular}

${ }^{1}$ In winter, the correction factor used was the one for adult rabbits (251). In summer (May - Sept.), when both young and adult rabbits occurred in cat diet, a mean correction factor for three rabbit size categories was used. The proportions of the size categories were determined on basis of rabbit teeth and bones in cat faeces (Liberg unpubl.).

Probably the prey intake would be a little higher, as the digestability of rodents, rabbits and other prey is not as high as the food given to the cats in the cited tests. It seems reasonable to assume that the amount of prey that cats of this size would need to fulfill their daily energy requirement, would lie somewhere between 240 and 270 grams. This is astonishingly close to the 282 grams that they actually ingested, as calculated on basis of faecal remains of prey and the correction factors arrived at in this study. I therefore conclude, that the validity of the correction factors and defecation rate, reported in this study, received strong support from the presented test.

\section{REFERENCES}

1. Brunner H. \& Coman B. J., 1974: The identification of mammalian hair. Inkata Press: 1-176, Melbourne, 
2. Fitzgerald B. M. \& Karl B. J., 1979: Foods of feral house cats (Felis catus L.) in forest of the Orongorongo Valley, Wellington. N. Zealand J. Zool., 6: 107-126.

3. Floyd T. J., Mech L. D. \& Jordan P. J., 1978: Relating wolf scat content to prey consumed. J. Wildlife Manage., 42: 528-532.

4. George W., 1974: Domestic cats as predators and factors in winter shortage of raptor prey. Wilson Bull., 86: 384-396.

5. Goszczyński J., 1974: Studies on the food of foxes. Acta theriol., 19: 1-18.

6. Greaves J. P., 1965: Protein and calorie requirements of the feline: [In "Canine and feline nutritional requirements", Ed. O. Graham - Jones] Pergamon Press: 33-45. Oxford. London, Edinburgh, New York, Paris, Frankfurt.

7. Hansson L. \& Grodziński W., 1970: Bioenergetic parameters of the field vole Microtus agrestis L. Oikos, 21: $76-82$.

8. Howard W. E., 1957: Amount of food eaten by small carnivores. J. Mammal. 38: $516-517$.

9. Liberg O., 1980: Spacing patterns in a population of rural free roaming domestic cats. Oikos, 35: $335-350$.

10. Lockie L. D., 1959: The estimation of the food of foxes. J. Wildl. Manage., 23: $224-227$.

11. Fyszkowski L., Goszczyński J. \& Truszkowski J., 1973: Trophic relationships of Microtus arvalis in cultivated fields. Acta theriol., 18: 125-165.

12. von Schantz T., 1980: Prey consumption of a red fox population in Southern Sweden. Biogeographica, 18: 53-64.

13. Scott P. P., 1968: The special features of nutrition of cats, with observations on wild Felidae in the London Zoo. Symp. Zool. Soc., London, 21: 21-36.

Accepted, July 20, 1981.

\section{Olof LIBERG}

\section{POPRAWKA DO WYLICZANIA WARTOSCI POZYWIENIA KOTÓW DOMOWYCH}

\section{Streszczenie}

Przeprowadzono eksperymenty pokarmowe w celu ocenienia relacji istniejącej między pozıomem spożytych ofiar a niestrawionymi ich częściami znajdywanymi w kale (= współczynnik poprawki) u kota domowego w poludniowej Szwecji (Tabela 1). Stwierdzono, że do oceny tej zależności użyte być mogą tylko włosy i pióra występujące $w$ kale (Tabela 2). Zmienność tego współczynnika, dla dużych ofiar takich jak dorosłe króliki, była szeroka. Określono też ilość ofiar zjadanych przez jednego kota $w$ ciągu doby oraz poziom defekacji (Tabela 3). Zaproponowano wprowadzenie równania, w celu dokładnego obliczania dobowego pobierania różnych ofiar. Poprawka była testowana $\mathrm{w}$ przedstawionym równaniu w próbach kału u dzikich kotów, które korzystają prawie całkowicie z naturalnych ofiar. Obliczona wartość dobowego pobierania tych ofiar różni się o około $15 \%$ nd spodziewanej wartości, opartej na teoretycznie wyliczonym dobowym zapotrzebowaniu energetycznym kotów. Wynika stąd, że przyjęte poprawki są włąściwe, 